\title{
Cardiorespiratory exercise performance after Senning operation for transposition of the great
} arteries

\author{
T Reybrouck, M Gewillig, M Dumoulin, L G van der Hauwaert
}

\begin{abstract}
Objective-To assess the cardiorespiratory response to graded exercise in patients after the Senning operation for transposition of the great arteries.

Design-Cross sectional study. Exercise performance was assessed by determination of the ventilatory anaerobic threshold. This was defined as the exercise intensity at which the ventilatory equivalent for oxygen $\left(\dot{V}_{E} / \dot{V}_{2}\right)$ started to increase systematically without a concomitant increase in the ventilatory equivalent for carbon dioxide $\left(\dot{\mathrm{V}}_{\mathrm{E}} / \hat{\mathrm{V}}_{\mathrm{CO}}\right)$. Setting-Outpatient department.

Patients-Sequential sample of 20 patients studied $5-10$ years (mean $7 \cdot 3$ years) after the Senning operation. Age at exercise testing varied from 5 to 11 (mean $7 \cdot 8$ ) years.
\end{abstract}

Results-The ventilatory threshold in the patients was significantly lower than normal (p < 0.005) and averaged 79.3\% (SD $13 \%)$ and $80 \%(12 \%)$ of the predicted normal value for age and weight, respectively. Also, the ventilatory threshold was surpassed sooner (mean $3 \cdot 2$ (range 2-5) minutes) in the patients than in normal controls $(3.9(2 \cdot 6-4 \cdot 6)$ minutes). The lower ventilatory threshold was associated with a subnormal oxygen uptake ( $\mathrm{ml} / \mathrm{min} / \mathrm{kg}$ ) during submaximal exercise, a higher than normal ventilatory equivalent for oxygen ratio, and a lower end tidal carbon dioxide tension in the patients compared with normal controls. In half of the patients heart rate was lower during graded exercise. This relative bradycardia was not associated with a normal ventilatory threshold, as often seen in fit young people. No major disturbances in rhythm were observed during exercise.

Conchusion-Exercise performance, assessed by respiratory gas exchange, was slightly but significantly lower than normal in patients after the Senning operation. A subnormal ventilatory threshold, associated with a higher than normal ventilatory response during submaximal exercise, supports the hypothesis that oxygen delivery to tissues is slightly impaired in these patients.

(Br Heart f 1993;70:175-179)

Several studies have documented a diminished exercise tolerance after the Mustard operation in patients with transposition of the great arteries. ${ }^{1-3}$ This has been related to an inappropriate increase of stroke volume and, to a less extent, a blunted heart rate response to exercise. ${ }^{45}$ Little information exists, however, about cardiorespiratory exercise performance in patients who have had the Senning operation. The theoretical advantage of the Senning procedure is that, in contrast to the Mustard operation, it uses almost exclusively viable atrial tissue, which has the potential for chamber growth and better preserves atrial contractility. We assessed the cardiorespiratory response to exercise in patients with transposition of the great arteries after the Senning procedure and compared it with previously published data in patients after the Mustard operation. ${ }^{2}$ Our assessment was based on the determination of the ventilatory (anaerobic) threshold, ${ }^{6-8}$ an evaluation of respiratory gas exchange and an analysis of heart rate response during submaximal exercise.

\section{Patients and methods}

Exercise studies were performed in 20 patients ( 15 boys and five girls) 4.7 to $10 \cdot 2$ (mean 7.2) years after the Senning operation for simple transposition of the great arteries. Age at surgery varied from 1 to 12 (6) months and age at exercise testing from 5 to $11(7 \cdot 8)$ years. All patients were symptom free. After operation they had yearly clinical, electrocardiographic, radiological, and echocardiographic examinations. Echocardiography showed patent venous pathways in all patients, a dilated right ventricle in 10 , and a mild to moderate dysfunction of the right ventricle in two (ejection fraction $<50 \%$ ); normal values were found in the others. ${ }^{9} \mathrm{~A}$ mild degree of tricuspid incompetence was observed in 14 of the 20 patients. At radiological examination cardiomegaly was found in four patients and a normally size heart in the others. Ambulatory 24 hour electrocardiograms were obtained in 17 of the 20 patients. All but two patients had a stable sinus rhythm, one having a permanent nodal rhythm and the other an intermittent sinus and nodal rhythm. Ventricular arrhythmia was classified according to the grading system of Lown et al. ${ }^{18}$ In eight patients no ventricular arrhythmia was recorded (grade 0), in five isolated premature ventricular contractions were recorded (fewer than 30 an hour and less than one per minute; grade 1A), in three multifocal premature ventricular contractions were recorded (grade 3), and in one a short period of complete atrioventricular 
block was recorded. The overall result of surgery was considered to be excellent. An electrocardiogram taken at rest before the exercise test showed stable sinus rhythm in 16 patients, intermittent atrioventricular nodal rhythm in two, and permanent nodal rhythm in two. Ventilatory thresholds, to assess exercise performance, were also compared with our previous data on patients who underwent the Mustard operation for transposition of the great arteries. ${ }^{2}$

\section{EXERCISE TESTING PROCEDURES}

The methods used for exercise testing have been fully described. ${ }^{8}$ Informed consent was obtained from the patients or the parents after the nature of the tests was explained. Graded exercise testing was performed on a treadmill. The inclination was increased by $2 \%$ every minute, the speed remaining constant at $4.8 \mathrm{~km} / \mathrm{h}$ and $5.6 \mathrm{~km} / \mathrm{h}$ for children below and above 6 years old, respectively. A 12 lead electrocardiogram was recorded continuously during exercise. Oxygen uptake, carbon dioxide output, and derived variables were measured in each breath. Expired flow was directed to a heated Fleish pneumotachograph (No 3) connected to a Validyne differential pressure transducer. Gas was continuously sampled at the mouthpiece with heated sample lines and its composition was analysed by a fast responding oxygen analyser (Sensormedics OM11) and an infrared carbon dioxide analyser (Beckman LB2). These signals were processed via an analog to digital converter to a personal computer for off line analysis. During validation studies this system showed no significant difference with the Douglas bag method. ${ }^{11}$ Before each exercise study the system was calibrated with known volumes of air flow and precise gas mixtures. The breaths were averaged and expressed as minute volumes. The Douglas bag method was used to measure respiratory variables ${ }^{8}$ in six patients who were studied before 1990 .

Cardiorespiratory exercise performance was assessed by determining the ventilatory threshold, defined as the highest exercise intensity before the ventilatory equivalent for oxygen $\left(\dot{\mathrm{V}}_{\mathrm{E}} / \dot{\mathrm{VO}}_{2}\right)$ started to increase steadily without a concomitant increase in the ventilatory equivalent for carbon dioxide $\left(\dot{\mathrm{V}}_{\mathrm{E}} / \mathrm{VCO}_{2}\right){ }^{6-8}$ In doubtful cases the $\mathrm{V}$ slope method was used, which shows a steeper increase in carbon dioxide output compared with oxygen uptake above the ventilatory (anaerobic) threshold. ${ }^{612}$

The ventilatory threshold was expressed as oxygen uptake $(\mathrm{ml} / \mathrm{min} / \mathrm{kg})$ or in units of time. Heart rate, expressed as a percentage of the normal mean value, was considered to be subnormal when it fell below the $95 \%$ confidence interval of the normal mean value. Ventilatory threshold, heart rate, oxygen uptake, and the ventilatory equivalent for oxygen in these patients were compared with values obtained in 234 age matched healthy children. ${ }^{13}$ To obtain normal reference values for end tidal carbon dioxide tension, data were obtained from a group of 14 normal controls of comparable age.
HABITUAL LEVEL OF PHYSICAL ACTIVITY

The children's daily level of physical activity was assessed by a standardised questionnaire. Information was obtained about the number of hours spent playing sports and participating in other leisure activities and about how the patients moved to and from the school. The number of hours of physical activity were accumulated as a score. When repeated within a month the scores were highly reproducible. $^{8}$

\section{STATISTICS}

Differences between mean values were calculated by univariate analysis of variance, analysis of variance with repeated measurements, or a Wilcoxon signed rank test. The dispersion of the data was described by the standard deviation of the mean and for normal children also by the $95 \%$ confidence intervals ${ }^{14}$ of the age predicted normal value.

\section{Results}

CARDIORESPIRATORY RESPONSE TO EXERCISE

The ventilatory threshold during exercise was determined in 15 of the 20 patients (fig 1 ). In five patients the intensity of the initial exercise level was already above the ventilatory threshold. The mean value averaged $79.3 \%$ (SD $13 \%)$ and $80 \%(12.5 \%)$ of the predicted normal value for age and weight, respectively, and was significantly lower than normal $(p<$ 0.001 ). Compared with normal controls of the same sex and age the ventilatory threshold was surpassed sooner during incremental exercise and was reached after a mean interval of 3.2 minutes (range 2-5) compared with 3.9 minutes $(2 \cdot 6-4.6)$ in controls $(p<$ 0.005).

Oxygen uptake was significantly lower at all levels of exercise in the patients than in controls (fig 2). At all levels of exercise the end tidal carbon dioxide tension was significantly lower in patients than in controls and the ventilatory equivalent for oxygen was significantly higher (table).

In the 12 patients who underwent the Mustard operation for transposition of the great arteries the initial exercise intensity was above the ventilatory threshold in four patients and no ventilatory threshold could be determined in one patient. ${ }^{2}$ The mean value

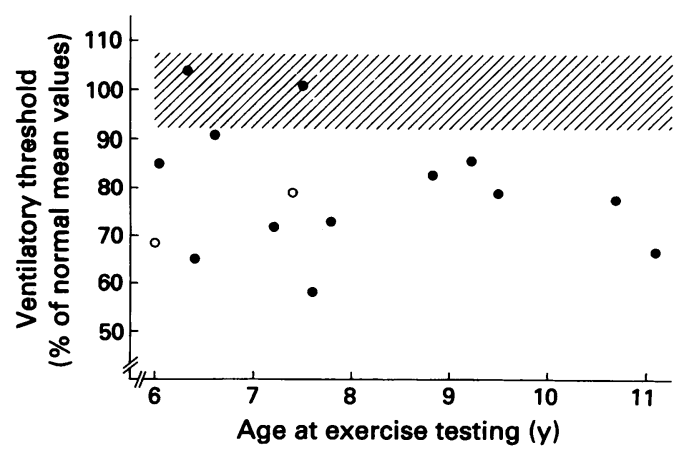

Figure 1 Individual values for ventilatory threshold in 13 boys (O) and two girls (O) operated on for transposition of the great arteries. 95\% Confidence intervals of normal mean value are shown by shaded area. 
Figure 2 Mean oxygen uptake ( $\mathrm{ml} / \mathrm{min} / \mathrm{kg}$ ) during graded treadmill exercise in 15 patients with transposition of the great arteries (O) and in healthy children of same sex and age (O). Vertical bars show standard deviations. $F=12 \cdot 2, p=0.002$ refers to comparison between patients and controls at all exercise levels and $F_{1}=2 \cdot 1, p>0 \cdot 10$ refers to interaction between the difference in subjects and exercise intensity.

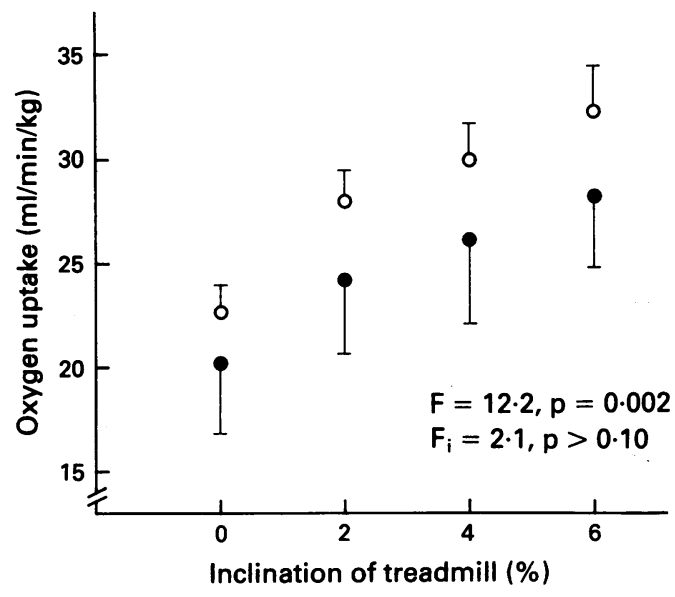

for the ventilatory threshold in the Mustard group averaged $80 \%(9.7 \%)$ and $75 \%$ $(12.4 \%)$ of the predicted normal value for age and weight, respectively.

\section{HEART RATE RESPONSE TO EXERCISE AND CARDIAC RHYTHM}

In 19 patients heart rate was monitored at all exercise intensities. When expressed as a percentage of the age predicted normal value, a subnormal value - that is below the $95 \%$ confidence interval-was found in 10 patients for two levels of exercise (fig 3 ). In all but one of these patients a subnormal value was found for the ventilatory threshold. In eight of the remaining nine patients heart rate was within normal limits for at least two levels of exercise.

The ventilatory threshold in these eight patients was subnormal in two, was already surpassed at the onset of exercise in five, and was normal in only one patient. One patient had a heart rate response above the $95 \%$ confidence interval (fig 3) with a subnormal ventilatory threshold. No relation was found between the heart rate response and the ventilatory threshold.

No major ventricular or atrial arrhythmia was observed during exercise. Fourteen patients had a stable sinus rhythm at rest and during exercise, and two patients had intermittent sinus and nodal rhythm at rest and during exercise. Two patients had nodal rhythm which changed to a sinus rhythm in one and remained a nodal rhythm in the

Cardiorespiratory variables during graded treadmill exercise in patients with transposition of the great arteries and in normal controls. Values are means (SD).

\begin{tabular}{|c|c|c|c|c|}
\hline & \multicolumn{4}{|c|}{ Exercise intensity (\% inclination of treadmill) } \\
\hline & 0 & 2 & 4 & 6 \\
\hline $\begin{array}{l}\text { Patients } \\
\text { Controls }\end{array}$ & $\begin{array}{l}3.6(0.34) \\
4.6(0.46)\end{array}$ & $\begin{array}{c}P_{E T} \mathrm{CO}_{2}(\mathrm{kPa}) \\
3.6(0.42) \\
4.7(0.45)\end{array}$ & $\begin{array}{l}3.7(0.46) \\
4.7(0.41)\end{array}$ & $\begin{array}{l}3.7(0.51)^{\star} \\
4.8(0.43)\end{array}$ \\
\hline $\begin{array}{l}\text { Patients } \\
\text { Controls }\end{array}$ & $\begin{array}{l}41 \cdot 3(10 \cdot 5) \\
36 \cdot 4(29)\end{array}$ & $\begin{array}{l}\dot{V}_{B} / \dot{V} O_{2} \\
39 \cdot 3(8) \\
32 \cdot 1(25)\end{array}$ & $\begin{array}{l}39 \cdot 4(8 \cdot 2) \\
32.9(25)\end{array}$ & $\begin{array}{l}39 \cdot 7(9) t \\
33(27 \cdot 2)\end{array}$ \\
\hline $\begin{array}{l}\text { measuren } \\
\mathrm{t}=\mathbf{F}=\mathbf{8}\end{array}$ & $\begin{array}{l}\mathrm{p}<0.001 \\
\text { nts at all exe } \\
\mathrm{p}<0.006\end{array}$ & $\begin{array}{l}\text { analysis of } \\
\text { ise levels). } \\
\text { analysis of } \\
\text { ise levels). }\end{array}$ & $\begin{array}{l}\text { f variance } \\
\text { variance }\end{array}$ & $\begin{array}{l}\text { of repeated } \\
\text { of repeated }\end{array}$ \\
\hline
\end{tabular}

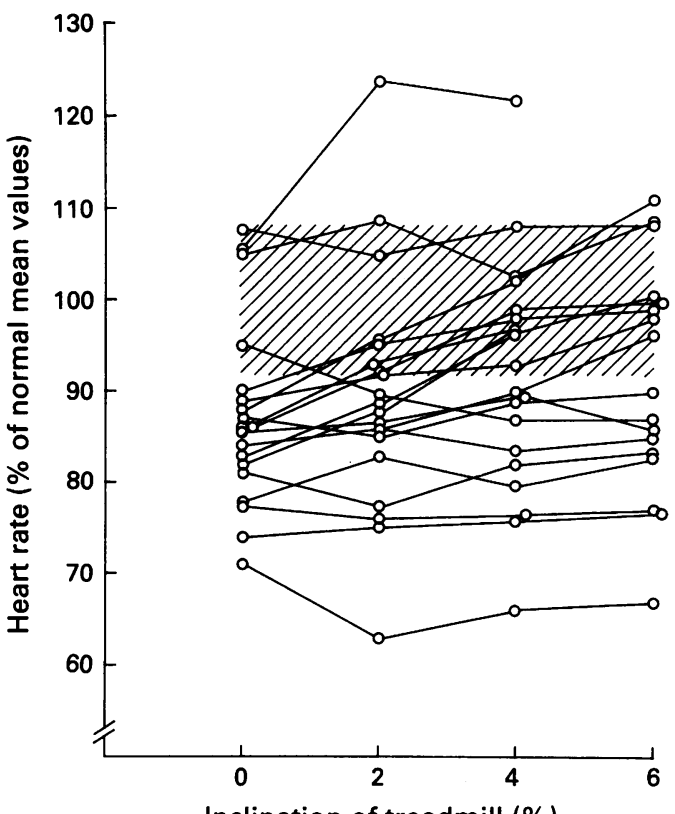

Inclination of treadmill (\%)

Figure 3 Individual responses to graded treadmill exercise in 19 patients with transposition of the great arteries. $95 \%$ Confidence intervals of normal mean value are shown by shaded area.

other during exercise. Finally, one other patient had a sinus rhythm at rest which changed to an intermittent sinus and nodal rhythm during exercise.

\section{RELATION BETWEEN EXERCISE PERFORMANCE AND CLINICAL DATA}

Exercise performance capacity, assessed by the ventilatory threshold and expressed as a percentage of the predicted normal value for age, was not significantly correlated with the time interval between surgery and exercise testing $(r=-0 \cdot 10, p>0 \cdot 25)$. The habitual level of physical activity, expressed as a score, was slightly but significantly lower in the patients (3.1 (0.9)) compared with healthy children of the same sex and comparable age $(3.6(0.7))(p<0.05)$. In contrast to normal controls, none of the patients played competitive sports.

The two patients with right ventricular dysfunction at echocardiographic examination had severely reduced ventilatory thresholds.

\section{Discussion}

Five to 10 years after the Senning operation for transposition of the great arteries most patients had a slightly or moderately reduced cardiorespiratory exercise performance, as assessed by the ventilatory threshold (mean $79 \%(13 \%)$ of the age predicted value). This compares with a mean value of $80 \%(9.7 \%)$ in patients six to 15 years after the Mustard operation. Similar, slightly decreased values for ventilatory threshold were found by Bowyer et al. ${ }^{15}$ From these studies exercise performance capacity was not significantly better after the Senning procedure than after the Mustard operation, despite the Senning procedure's potential for tissue growth and better atrial contractility. 
We chose the ventilatory threshold to assess cardiorespiratory exercise capacity because it measures submaximal cardiorespiratory fitness, which is not affected by a child's motivation to perform maximal exercise, such as is to measure required maximal oxygen uptake. Although its exact physiological mechanisms are still debated, ${ }^{12} 15$ the ventilatory threshold usually coincides with the highest exercise intensity which can be performed for some length of time without developing dyspnoea and fatigue. It may be more clinical relevant than maximal oxygen uptake because it relates to common daily physical activities.

Exercise performance capacity is reduced after atrial repair by the Mustard operation ${ }^{1-3}$ and has been attributed to right ventricular dysfunction. ${ }^{16-18}$ This may lead to an inappropriate increase of right ventricular ejection fraction and stroke volume and a subnormal cardiac output during exercise. ${ }^{17-19}$ Our findings of reduced oxygen uptake during submaximal exercise, earlier onset of hyperventilation, and a higher than normal ratio of ventilatory equivalent for oxygen $\left(\dot{\mathrm{V}}_{\mathrm{E}} / \dot{\mathrm{VO}}_{2}\right)$ to lower end tidal carbon dioxide tension are in accordance with a slight or moderate haemodynamic disturbance. The delivery of oxygen to the tissues seems to be impaired in these patients, resulting in a higher than normal anaerobic to aerobic energy supply and a reduced exercise tolerance.

Another factor that may contribute to a reduced exercise performance is an impaired chronotropic response to exercise. In about half of our patients heart rate was lower than normal during exercise. This agrees with the results of exercise studies in patients after a Mustard operation, many of whom were found to have a junctional or comparatively slow sinus rhythm. ${ }^{12021}$ Theoretically, a low ventilatory threshold and impaired $\mathrm{O}_{2}$ delivery to tissues can be compensated for by a higher heart rate, as seen in unfit people, ${ }^{22}$ but this compensatory mechanism was not found in our patients.

The loss of sinus rhythm seen in two of our patients has been described by other investigators after the Senning and Mustard operations. ${ }^{2324}$ The most frequent form of arrhythmia after intra-atrial surgery for transposition of the great arteries was the development of atrioventricular nodal rhythm. The two patients who developed nodal rhythm in our study had a subnormal heart rate response during exercise and a subnormal exercise capacity. Major arrhythmia did not appear during exercise testing in our series. Also, in the studies of Bender et $a l$ and Turina et al the incidence of serious rhythm disturbances was low within 10 years after the Senning operation, ${ }^{23} 25$ but it remains a concern.

Finally, although our patients were symptom free and normally active during low intensity physical activity, they were not engaging in strenuous exercise and formal sporting activities. Physical activity during leisure time was not medically restricted, but they were discouraged to participate in competitive sports. The earlier onset of hyperventilation and anaerobic metabolism may to some extent be explained by hypoactivity and exercise intolerance at heavier levels of physical activity. Although, all children in our study led a normal and active life, longer follow up studies are needed to determine whether late complications, mainly right ventricular dysfunction, might impair their exercise tolerance in adult life.

This study was supported in part by grants of the National Research Council (NFWO (S 2/5-LV.E78)) and by the National Lottery of Belgium.

1 Ensing GJ, Heise CT, Driscoll DJ. Cardiovascular response to exercise after the Mustard operation for simple and complex transposition of the great arteries. Am $\mathcal{F}$ Cardiol 1988;62:617-22.

2 Reybrouck T, Dumoulin M, Van der Hauwaert LG. Cardiorespiratory exercise testing after venous switch Cardiorespiratory exercise testing after venous switch
operation in children with complete transposition of the operation in children with complete transposit

3 Musewe NN, Reisman J, Benson LN, Wilkes D, Levison $\mathrm{H}$, Freedom RM, et al. Cardiopulmonary adaptation a rest and during exercise 10 years after Mustard atria repair for transposition of the great arteries. Circulation 1988;77:1055-61.

4 Mathews RA, Fricker FJ, Beerman LB, Stephenson RI, Fischer DR, Neches WM, et al. Exercise studies after the Mustard operation in transposition of the great arteries. Am f Cardiol 1983;51:1526-9.

5 Hesslein PS, Gutgesell HP, Gilette PC, McNamara DG. Exercise assessment of sinoatrial node function following the Mustard operation. Am Heart $f$ 1982;103:351-7.

6 Wasserman K. Determinants and detection of anerobic threshold and consequences of exercise above it. Circulation 1987;76(suppl VI):29-39.

7 Sullivan MJ, Cobb FR. The anerobic threshold in chronic heart failure. Relation to blood lactate, ventilatory basis, reproducibility, and response to exercise training. Circulation 1990;81 (suppl II):47-58.

8 Reybrouck T, Weymans M, Stijns H, Van der Hauwaer LG. Exercise testing after correction of tetralogy of Fallot: the fallacy of a reduced heart rate response. $A m$ Heart $f$ 1986;112:998-03.

9 Ninomya K, Duncan W, Cook D, Olley P, Rowe P. Right ventricular ejection fraction and volumes after the Mustard repair: correlation of two dimensional echocardiogram and cineangiogram. Am $f$ Cardiol. 1981; 48:317-24.

10 Lown B, Calvert AF, Armington R, Ryan M. Monitoring for serious arrhythmias and high risk of sudden death for serious arrhythmias and high risk of

11 Reybrouck T, Deroost F, Van der Hauwaert LG. Evaluation of breath-by-breath measurement of respiraEvaluation of breath-by-breath measurement of respiratory gas exchange

12 Dickstein K, Barvik S, Aarsland T, Snappins S, Karlsson $J$. A comparison of methodologies in detection of anaerobic threshold. Am $\mathcal{F}$ Cardiol 1990;81 (suppl II):38-46.

13 Reybrouck T, Weymans M, Stijns H, Knops J, Van der Hauwaert LG. Ventilatory anaerobic threshold in healthy children: age and sex differences. Eur $\mathcal{F} A p p$ Physiol 1985;54:278-84.

14 Snedecor GW, Cochran WC. Statistical methods. 5th ed Ames, Iowa, Iowa State University Press, 1972.

15 Bowyer J, Busst CM, Till JA, Lincoln C, Shinebourne EA. Exercise ability after Mustard's operation. Arch Dis Child 1990;65:865-70.

16 Benson LN, Bonet J, McLaughlin P, Olley PM, Feighlin $\mathrm{D}$, Druck $\mathrm{M}$, et al. Assessment of right ventricular function during supine exercise after Mustard's operation. tion during supine exercise

17 Alpert BS, Bloom KR, Olley P, Trusler GA, Williams CM, Rowe ED. Echocardiographic evaluation of right $\mathrm{CM}$, Rowe ED. Echocardiographic evaluation of right
ventricular function in complete transposition of the ventricular function in complete transposition of the great arteries: ang
$1979 ; 44: 270-5$.

18 Martin RP, Qureshi SA, Ettedgui JA, Baker EJ, O'Brien EJ, Deverall PB, et al. An evaluation of right and left ventricular function after anatomical correction and intra-atrial repair operations for complete transposition of the great arteries. Circulation 1990;82:802-6.

19 Peterson RJ, Franch RH, Fajman WA, Jones RH Comparison of cardiac function in surgically corrected and congenitally corrected transposition of the great arteries. F Thorac Cardiovasc Surg 1988;96:227-36.

20 Wong KY, Venables AW, Kelly MJ, Kalff V. Longitudina study of ventricular function after the Mustard operation for transposition of the great arteries: a long term follow-up. Br Heart $\mathcal{f}$ 1988;60:316-23.

21 Warnes CA, Sommerville J. Transposition of the great arteries: late results in adolescents and adults after the Mustard procedure. Br Heart $\mathcal{f}$ 1987;58:148-55.

22 Hammond HK, Froehlicher VF. Normal and abnormal heart rate response to exercise. Progr Cardiovasc Dis 1985;27:271-96. 
23 Bender HV, Stewart JR, Merill WH, Hammon JW, Graham TP. Ten years' experience with the Senning operation for transposition of the oreat arteries; physiologic results and late follow-up. Ann Thorac Surg logic results and

24 Deanfield J, Camm J, Macartney F, Cartwright $T$ Douglas J. Drew J, et al. Arrhythmia and late mortality after Mustard and Senning operation for transposition of the great arteries. F Thorac Cardiovasc Surg 1988;96: 569-76.

25 Turina MI, Siebenmann $R$, Von Sogesser L, Schönbeck $M$, Senning A. Late functional deterioration after atrial $M$, Senning A. Late functional deterioration after atrial correction for transposition of the great arteries.
Circulation 1989;80(suppl I):1162-7. 